\title{
Ethnicity in Post-Independent India: A Sociological Perspective on Its Causes and Manifestations
}

\author{
Arya Priya \\ Research Scholar; PhD (Sociology); Centre for the Study of Social Systems (CSSS)/School of Social Sciences \\ (SSS); Jawaharlal Nehru University (JNU); New Delhi. India.
}

\begin{abstract}
The surge in ethnic unrest and conflicts in India in recent years has become a matter of serious concern. Linguistic assertions, communalism, regionalism, caste conflictsand tribal identity movements-all are on the rise. They are not only choking the developmental efforts but also threatening the unity and integrity of the nation. Acute poverty and inequality, political maneuvering and deleterious effects of hasty globalization are some of the critical factors responsible for the intensification of ethnic assertions in India. This paper is an attempt to look into the causes and manifestations of heightened ethnicity in India and also the response of the Indian state to such ethnic turmoil and conflicts.
\end{abstract}

Keywords: casteism, communalism, ethnicity, ethno-nationalism, regionalism.

\section{Introduction}

An ethnic group is a group of people united on the basis of some shared experience or some common physical or socio-cultural attributes. For e.g. race, culture, language, religion, region, nationality, heritage etc. Yinger (1997: 3-4) defines ethnic group as a segment of a larger society which is seen by others to be different in some combination of the following characteristics - language, religion, race and ancestral homeland with its related culture; the members of the ethnic group also perceive themselves in that way and they participate in shared activities built around their (real or mythical) common origin or culture. Weber (1997: 18-19) defines ethnic groups as those groups which entertain a subjective belief in their common descent because of similarities of physical types or customs or both. This subjective belief is important for the propagation of group formation. Furthermore, it does not matter whether or not an objective blood relation exists.

Ethnicity involves a feeling of consciousness among the members of an ethnic group of the existence of such shared characteristics. It also involves the process of mobilization of people along some common point of reference for presenting a united front to articulate their socio-economic or political interests. Ethnicity, thus, involves the process of interaction between two or more groups. Barthes (1969) says that the issue of the identification of social boundary is intrinsic to the concept of ethnicity. Each ethnic group draws a boundary to identify its own members and to distinguish the "we" group from other ethnic groups.

Geertz (1996: 40-45) avers that ethnicity is based on the primordial ties of blood, race, language, religion or tradition and such 'attachments seem to flow from a sense of natural affinity than from social interaction' ( $p$ 42). However, many sociologists do not agree with Geertz's views on ethnicity that it is based on primordial loyalty and is immutable. Writing on ethnicity in South Asia, Phadnis and Ganguly (2001) posit that ethnicity is a dynamic and fluid concept. Its basis is not pre-determined but keeps on changing depending on the circumstances existing at a particular time. A person's identity is multi-faced and keeps on flitting from one to another depending on the circumstances. For instance, ethnicity based on religion at one time may give way to another like region or language whenever there is a change of interest or circumstances.

Another important concept is that of ethno-nationalism. Ethno-nationalism is on rise in recent years due to large-scale trans-national migrations in the current era of unprecedented globalization. According to Anthony Smith (1993) 'ethnic nationalism...unlike the territorial or civic versions of nationalism....conceives of the nation as a genealogical and vernacular cultural community. Whereas civic or territorial conceptions of the nation regard it as a community of shared culture, common laws and territorial citizenship, ethnic concepts of the nation focus on the genealogy of its members, however fictive; on popular mobilization of the 'folk'; on native history and customs; and on the vernacular culture...'(cited in Phadnis et al. 2001).

\section{Ethnic Unrest In India - Major Factors}

India has been a witness to rising ethnic tensions and conflicts in recent years. Many sociologists have, quite rightly, highlighted the problems encountered in the process of nation-building as a consequence of increasing ethnic problems. Kothari (1988) asserts that ethnic upsurges and 'assertions of cultures' in India are the consequences of excesses of modernization and the homogenizing trend of modern states and of their technological/educational imperatives. In his words, ethnicity 'is a response-including reaction - to the excesses 
of the modern project of shaping the whole humanity (and its natural resource base)...' (ibid.: 16). Such views are also echoed by scholars like Pandey (1990) and Oberoi (1994) who consider recent surge in ethnic assertions a consequence of modernity and that traditional India was free from such fixed identities. However, the noted scholar and Dalit activist Gail Omveldt (1990: 726) criticizes such a romanticized view of traditional India. She holds that traditional India was not characterized by multiculturalism but by hierarchy which pervaded every aspect of social life.

Some of the critical factors responsible for inflamed ethnicity in India are:

- India is a plural society. It is characterized by a large diversity in its population with multitudes of castes and several religious, linguistic, cultural and racial groups living here. Because of intense competition for scarce economic resources and the heightened consciousness among people of different groups to preserve their age-old cultures, India has always been vulnerable to assertions of ethnic identities.

- Lopsided economic development of the country because of which some groups feel that they have been marginalised and completely left behind in the process of development. This makes them highly susceptible to the politics of ethnicity.

- Representative parliamentary democracy in India where different ethnic groups (castes, religious groups, linguistic groups etc.) compete for political power by stressing on horizontal solidarity and consolidation of shared interests.

- Increasing politicization of caste and religion. Caste and religious identities are often whipped up by political leaders to mobilize people for their vested interests and petty political mileages.

- Fear among minorities (both linguistic and religious) that they might get assimilated into the dominant culture leading to the dilution of their cultural heritage. Hence, there is an increasing stress on ethnic identity to forge horizontal solidarity. Such feelings have also increased because of the process of globalization and cultural homogenization occurring everywhere. Cultural globalization is even causing the Hindu majority to assert itself and is spawning Hindu revivalism in India.

- Intense feeling of alienation among the tribes of India because of faulty development policies, leading to forced displacement from their age-old inhabited land and forest, reducing them to abject poverty and destitute.

\section{Manifestations Of Ethnic Turmoil And Conflict In India}

The articulation of ethnic identity and assertion in India primarily takes the following forms:

a) Linguistic Ethnicity: Language has always formed the basis of asserting ethnic identity in India. This was well evident during the Dravida Kazhagam (Dravidian Organization) movement in the state of Tamil Nadu in South India in 1940s and 1950s when violent protest broke out against the adoption of Hindi as the national language by the government of India. The movement gave the call for the secession of Tamil Nadu from the union of India on the basis of identity centered on Tamil language. Because of intense linguistic feelings, many states were carved out based on languages by the State Reorganization Act of 1956. Recently, linguistic identity was again on display in the state of Maharashtra in Central India, where in the name of Marathi pride, there were concerted attacks on the helpless and poor Hindi-speaking North Indian immigrants from the states of Bihar and Uttar Pradesh.

Writing on linguistic identity, Vanaik (1990) says linguistic ethnicity came into existence in India along with the growth of the national movement. To quote him 'Linguistic community as a linguistic community did not so much precede the rise of nationalist consciousness and nationalist struggle as developd along with and through it' (ibid.: 6). Vanaik contends that unlike religion, linguistic consciousness is never a powerful contender for separate nationhood because for most Indians, linguistic consciousness co-exists nonantagonistically with national consciousness. Oommen (1990) makes similar argument. Comparing language and religion, he says that language has more legitimacy than religion for administrative restructuring. It is premature to assume that movements for cultural identity constitute a threat to India. In fact, further provincial demarcations on finer linguistic lines are good for the stability of Indian nation-state. India should accept and acknowledge cultural pluralism and strive to build a multi-cultural society. The averments of both Vanaik and Oommen have merit as linguistic ethnicity has hardly posed a severe challenge to the very unity and integrity of India. In fact, the Dravida Kazhagam, in 1960s, got co-opted into the national political mainstream and gave rise to two formidable regional political parties in Tamil Nadu, the DMK (Dravida Munnetra Kazhagam) and the AIADMK (All India Anna Dravida Munnetra Kazhagam).

b) Religious Assertions And Communalism: This is probably the most difficult and intricate socio-political issue that the Indian state has to grapple with when it comes to nation-building, especially the communal tension between the Hindus and the Muslims. Mutual distrust between the two communities in very high. 
The recent surge in Hindu nationalism has further intensified the feeling of cultural assertiveness on both sides. Post-independent India is replete with gory incidents of Hindu-Muslim riots.

Writing on communal strife in India, noted historian Chandra (1999: 131-164) holds that communalism in India is a modern phenomenon. It has its roots in British imperialism and emerged out of modern politics based on mass mobilization and imaginary communal interests. The British policy of 'divide and rule' in India sowed the seeds of antagonism and distrust between the Hindus and the Muslims so deep that the process of bridging the chasm between the two communities is still far from over. Communalism is basically an ideology that spawns hatred based on religious constructions. In modern times, Indians have become highly susceptible to being swayed by communal ideologies and tendencies. Huge population of India causing acute populationresource imbalance, uneven development leading to poverty, inequality and unemployment and the politics of hatred and cynicism have created huge disaffection among the people especially among the youth. Under these circumstances, they see other communities as responsible for their deprivations and abject conditions. Such passions are generally whipped up by religious leaders and unscrupulous politicians for their vested interests. Chandra asserts that animosity based on religion always has underlying socio-economic factors. Communal flare-up or communal riots are just an outward manifestation of this deep-rooted communal ideology. What we have to really fight against in modern India is this deeply entrenched ideology of antipathy and aversion based on religious constructions.

c) Tribal Movements: This is not unique to post-independent India. The British period was full of incidents when tribes rose in revolt against the officials, the landlords and the money-lenders when they were forcibly evicted from their traditional land. Even in independent India, the tribes constitute the most neglected lot. Their lack of development and displacement from forests and traditional lands has caused huge disaffection among them. This has led to the resurgence of tribal identity movements in different parts of the country. An important dimension of this is what is called the 'ethno-ecological' movement in which the tribes are not only fighting against their displacement but also against the ecological destruction of their natural habitats. The growing menace of Maoist violence in India (also called naxalism) in the tribal dominated regions of the country, where the tribes are engaged in armed rebellion against the state, is a direct consequence of their oppression, displacement, poverty and anger against their cultural erosion under the onslaught of the dominant mainstream culture.

[A map of India showing the naxal affected regions is presented in the end].

d) Ethno-Nationalism: This entails the transformation of ethnic groups into nationalities and their demand for autonomous governance or even secession as sovereign nation states. For e.g. the secessionist movement in Kashmir, the Khalistan movement by Sikhs in Punjab in 1970s and 1980s for a separate homeland and the Naga movement in North-East India.

While commenting on ethno-nationalism in Punjab, Gupta (1990: 521-38) avers that the existence of ethnic identity or consciousness of some shared characteristics, per se, is not a sufficient condition for the rise of ethnic conflict. It is the mobilization and manipulation of group identity by the political leadership that leads to ethnicity. He used the term 'conspiracy' to denote the deliberate and calculated manipulation on which such ethnic politics is based. Gupta says that the Punjab agitation began with very secular demands like demands for the city of Chandigarh, water distribution and territorial demarcation, but it was soon ethnicized by the political masters and given a communal color as if they were fighting to safeguard the religious and regional identity of Sikhs in Punjab. Delving on ethno-nationalism in Kashmir, Varshney (2010) says that Kashmir presents a very intricate and complex situation. The ethno-nationalism that animates the Kashmiri aspirations for independence has many internal contradictions - it appeals only to the Muslims in the Kashmir valley, but not to the Hindus in the city of Jammu or Buddhist in the region of Ladakh. Varshney observes that maintaining peace and territorial integrity of Kashmir would be the ultimate test of India's secular credentials.

e) Regionalism: Centers around three main factors: i) fear of being assimilated into the dominant culture and, hence, to preserve one's language and culture by demanding an autonomous state, ii) the skewed economic development of India where certain groups feel that they have been left behind despite being rich in resources in their regions and iii) nativistic tendencies - 'sons of the soil' concept in which regional identity becomes the source of ethnic strife. Examples include the erstwhile Jharkhand movement in the state of Bihar and Telangana movement in the state of Andhra Pradesh, the attack on South Indians in Mumbai in 1960s and the simmering movement in the north-eastern state of Assam to expel the immigrants especially 
from the states of Bihar and Uttar Pradesh, which ofter taken the ugly turn of sanguinary strife between the natives and the immigrants.

f) Casteism: A rather inconclusive debate rages as to whether caste can be considered an ethnic group. A large chunk of that debate centers around the relation between caste and race. Scholars such as Berreman (1963) contend that caste is quite akin to race in its attributes and have highlighted the striking parallels between the two; others such as Dumont (1961) hold that the caste system, indigenous to India, has several unique features of its own which prevent it from being subsumed within the larger rubric of race. Beteille (1992: 37) says that many American social anthropologists while working on racial segregation in the southern states of the United States in 1930s found it useful to speak of a caste system in representing the cleaveges between blacks and whites in rural and urban communities there. They found strong similarities between caste system and stratification based on race. In fact, Myrdal (1944) employed similar terms and categories in his classic study of the American Negro.

During the World Conference against Racism, Racial Discrimination, Xenophobia and Related Intolerance (WCAR) held in South Africa in 2001, several dalit activists made a strong pitch for the inclusion of caste within the rubric of race because of common features such as descent and birth defining them, intergenerational discrimination, and both race and caste as sources of institutionalised prejudices, biases and oppression. However, Beteille (2001) disagrees with the whole idea of equating caste with race. He avers 'treating caste as a form of race is politically mischevious...(and) scientifically nonsense.' Drawing on Franz Boas' (1940) assertion that race is a biological category and should be distinguished from other social groupings based on language, religion, nationality, style of life or status, Beteille (2001) says 'The practice of untouchability is reprehensible and must be condemned... but that does not mean we begin to regard it as a racial discrimination...Every social group cannot be regarded as a race simply because we want to protect it from prejudice and discrimination.' Cox (1945) also posits that while race relations are physical, caste relations are cultural. Further, race sentiments and interests tend to be universal; while caste sentiments and interests tend to be localised. If a part of the membership of a caste is to migrate to a distant area, the likelihood is that it would become a new caste; not so, however, with a race.

Within the broader frame of ethnicity, to Beteille (1992: 51), caste has a rather ambiguous position. The caste system may be viewed as a particular case of ethnic differentiation. Whether racial differences exist between castes or not, they are often differentiated from each other culturally, in their diet, dress and rituals. The boundaries between castes are also maintained by the rules of endogamy. However, in a caste system, different groups are all integrated within a hierarchical order. Ethnic groups are not necessarily arranged in a hierarchy and they are not always integrated within a unitary system.

However, it cannot be gainsaid that parliamentary democracy in India and the implementation of castebased reservation in jobs and in educational institutions have led to a heightened consciousness among different castes of shared socio-economic and political interests and a feeling among the members of a caste as belonging to one group. Caste has become an easy tool in the hands of the politicians to mobilize people. This is evident from the emergence of various caste based political parties in India such as the Bahujan Samaj Party (a Dalit based party) in the state of Uttar Pradesh or Rashtriya Janta Dal (a party of intermediate castes) in the state of Bihar. The increasing awareness of the caste groups sharing a common interest and, hence, some shared sociocultural attributes and the stress on horizontal solidarity have led to what Stephen Barnett (1975) calls 'the modern transformations of caste to ethnicization' (Reddy 2005: 547).

Commenting on caste-based ethnicity, Rudolph and Rudolph (1967: 32-36) hold that in a representative democracy like India, numerical strength is of great significance. It is in the interests of all castes to come together. That is why there is a spurt in caste associations and caste federations. Rudolph and Rudolph call these associations 'paracommunities'. These paracommunities enable caste members to come together and pursue social mobility and economic gains and political power collectively. According to Reddy (2005: 547), for Susan Bayly (1999), the ethnic character of caste lies in its becoming an 'urgent moral mandate' in Independent India, 'a bond of collective virtues and obligations on the basis of which public-spirited people should take decisive action when they hear the call to arms'. Bayly's analysis highlights the tendencies of caste groups to function as pressure groups or lobbies of sorts, emphasizing their propensities "towards rivalry and antagonism".

\section{Conclusion}

Paul Brass (1992) discusses the response of Indian state to ethnic tension in India. Indian state's response to ethnicity has been a mixed one. Overall, Paul Brass highlights the following responses of the Indian State: a) all demands short of secession have been allowed full expression, but secessionist demands have been out-rightly rejected; b) regional demands based on language/culture have been accommodated, but those based 
on religious differences have not been accepted; c) an ethnic demand has only been accepted when there is a broad-based popular demand for it and d) views of other affected groups involved in the dispute have also been taken into consideration in arriving at any conclusion.

India is a multi-cultural nation. Its diversity is its greatest strength. Forging unity among different ethnic groups holds the key to India's success as a vibrant democracy. This requires multi-pronged strategy - balanced regional development, inclusive economic development, safeguarding the interests of ethnic minorities and tribes, stamping out all communal and casteist tendencies and fostering a sustained interaction among different cultural groups in the country.

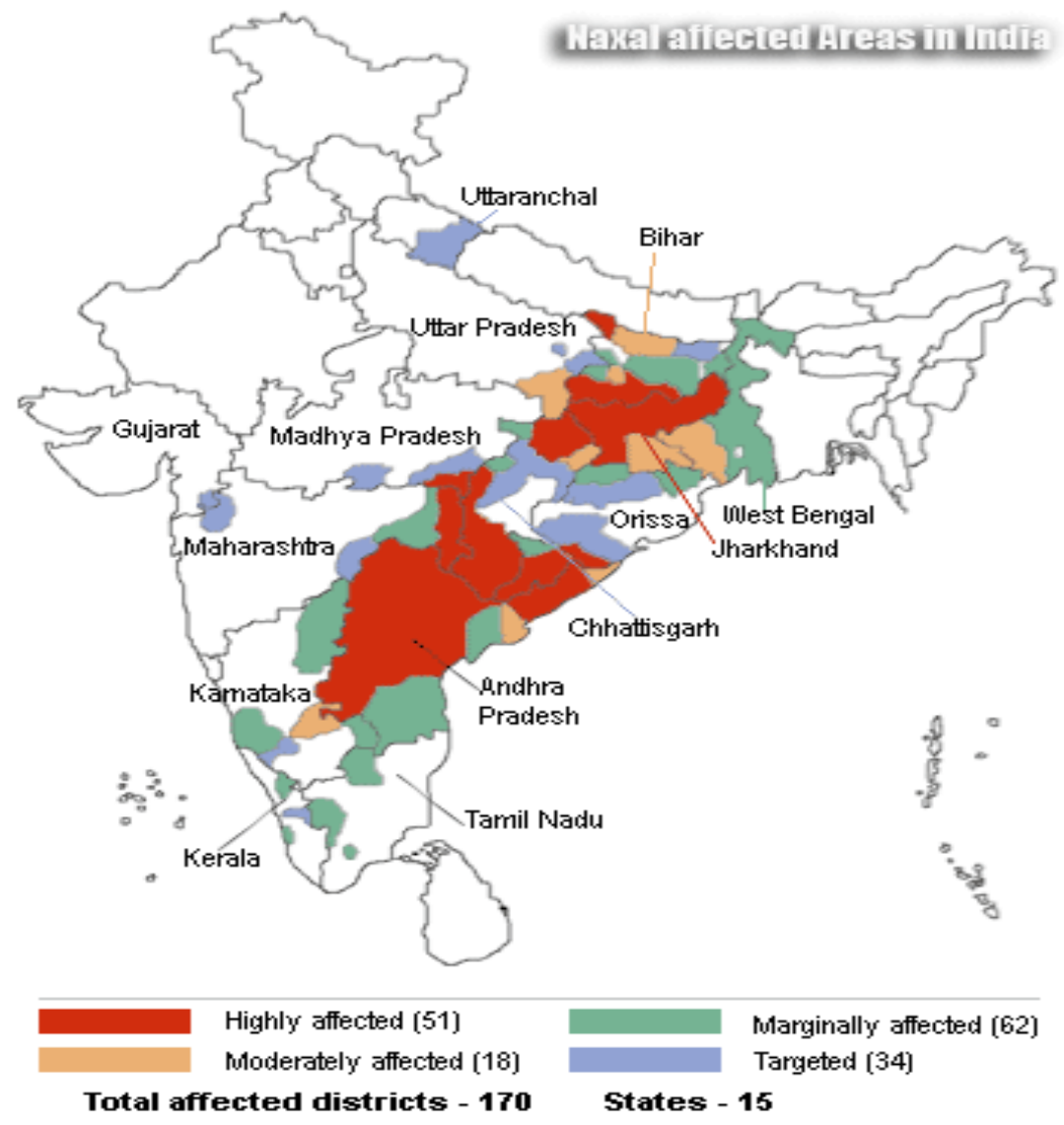

(Courtesy: CNN-IBN; retrieved on 27/12/15 from http://www.sangam.org/2009/08/Notes_Corridor.php/).

\section{References}

[1]. Barth, F. (1969). Ethnic Group and Boundaries. Boston: Little Brown

[2]. Barnett, Stephen. (1975). Approaches to Changes in Caste Ideology in South India. In Burton Stein (Ed.). Essays on South Asia. Hawaii: University of Hawaii Press.

[3]. Bayly, Susan. (1999). Caste, Society and Politics in India from the Eighteenth Century to the Modern Age. UK: Cambridge University Press.

[4]. Berreman, G. (1963). Hindus of the Himalayas. Berkeley: University of California Press.

[5]. Beteille, Andre. (1992). Society and Politics in India: Essays in a Comparative Perspective. New Delhi: Oxford University Press.

[6]. Beteille, Andre . (2001, March 10). Race and Caste. The Hindu.

[7]. Boas, Franz. (1940). Race, Language and Culture. USA: University of Chicago Press.

[8]. Brass, Paul. (1992). Ethnicity and Nationalism. New Delhi: Sage Publication.

[9]. Chandra, Bipan. (1999). Essays on Contemporary India ( $2^{\text {nd }}$ ed.). New Delhi: Har-Anand Punlications

[10]. Cox, Oliver. (1945). Race and Caste: A Distinction. American Journal of Sociology. Vol. 50, no. 5 (March, 1945), $360-68$.

[11]. Dumont, L. (1961). Caste, Racism and Stratification: Reflections of a Social Anthropologists. Contributions to Indian Sociology 5, $20-43$.

[12]. Geertz, C. (1996). Primordial Ties. In Hutchinson, J. \& Smith, A. (Eds.). Ethnicity. New York: Oxford University Press (40-45).

[13]. Gupta, Dipankar. (1990). The Indispensable Centre: Ethnicity and Politics in the Indian Nation State. Journal of Contemporary Asia, vol 20, 521-38.

[14]. Kothari, Rajani. (1988). State Against Democracy: In Search of Humane Governance. New Delhi: Ajanta Publication.

[15]. Myrdal, G. (1944). An American Dilemma: The Negro Problem in Modern Democracy. New York: Harper Publishers

[16]. Omveldt, Gail. (1990). Hinduism and Politics. Economic and Political Weekly, vol 25, 723-29.

[17]. Phadnis, U. \& Ganguly, R. (2001). Ethnicity and Nation-building in South Asia (Revised Edition). New Delhi: Sage Publications.

[18]. Oberoi, Harjot. (1994). The Construction of Religious Boundaries: Culture, Identity and Diversity in the Sikh Tradition. New Delhi: Oxford University Press. 
[19]. Oommen, T.K. (1990). Protest and Challenge: Studies in Social Movements. New Delhi: Sage.

[20]. Pandey, Gyanendra. (1990). The Construction of Communalism in Colonial North India. New Delhi: Oxford University Press.

[21]. Reddy, Deepa. (2005). The Ethnicity of Caste. Anthropological Quarterly, vol. 78, no.3, 543-584.

[22]. Rudolph, L., \& Rudolph, S. (1967). The Modernity of Tradition. University of Chicago: USA

[23]. Smith, A. (1993). The Ethnic Source of Nationalism. Survival 35 (Spring), 48-62.

[24]. Vanaik, Achin. (1990). The Painful Transition: Bourgeois Democracy in India. London: Verso

[25]. Varshney, A. (2010). Three Compromised Nationalism: Why Kashmir has been a Problem ? In Baruah, S. (Ed.). Ethnonationalism in India: A Reader. New Delhi: Oxford University Press (chapter 4).

[26]. Weber, Max. (1997). What is an Ethnic Group ? In Guibernau, M. \& Rex, J. (Eds.). The Ethnicity Reader. UK: Polity Press (15-26)

[27]. Yinger, Milton. (1997). Ethnicity. New Delhi: Rawat Publication. 